\title{
RESEARCH PAPER \\ Response of wheat seeds to zinc application during storage
}

\author{
Elisa S. Lemes ${ }^{1}$, Lilian M. de Tunes ${ }^{1}$, Andreia da S. Almeida ${ }^{1}$, Geri E. \\ Meneghello ${ }^{1}$, Sandro de Oliveira ${ }^{1}$, and Marlove F. B. Muniz ${ }^{2}$
}

${ }^{1}$ Federal University of Pelotas, Post Graduate Course in Seed Science and Technology. 96 001-970, Pelotas, Rio Grande do Sul, Brazil.

${ }^{2}$ Federal University of Santa Maria. 97 105-900, Santa Maria, Rio Grande do Sul, Brazil.

\begin{abstract}
E.S. Lemes, L.M. Tunes, A.S. Almeida, G.E. Meneghello, S. Oliveira, and M.F.B. Muniz. 2015. Response of wheat seeds to zinc application during storage. Cien. Inv. Agr. 42(1): 109-119. Seed coating is among the most potentially beneficial treatments to enhance seed performance, contributing to the improvement of crop stands due to its role in improved seedling development. Thus, micronutrients such as zinc exhibit potential for use in seed coatings. The objective of this research is to evaluate the effect of coating wheat seeds with zinc sulfate on traits that are related to seed quality during storage and nutrition efficiency during seedling growth. The levels of $\mathrm{ZnSO}_{4}$ used were $0,1,2,3$ and $4 \mathrm{~mL} \mathrm{~kg}^{-1}$ seed. After 0,3 and 6 months of storage, the germination percentage, mean root length, root dry mass, seedling emergence, nutritional efficiency (absorption, transport and use) and zinc content in the seeds were evaluated. Seed coating with $\mathrm{ZnSO}_{4}$ increased seedling dry weight and zinc content in roots, which are the primary sink for this nutrient. Higher rates of $\mathrm{ZnSO}_{4}$ coating resulted in higher absorption efficiency and a concomitant decrease in $\mathrm{Zn}$ transport and use efficiency. Thus, the application of appropriate doses of zinc to seeds increases the accumulation of this nutrient, resulting in well-nourished plants that present improved initial development under adverse conditions.
\end{abstract}

Key words: Seed vigor, Triticum aestivum L., Zinc coating.

\section{Introduction}

Since the beginnings of agriculture some 10,000 years ago, cereals have provided the main source of calories for the human diet. Recognized for their high yields, nutritional value, and ease of transport and storage, many cereals were domesticated by the world's first farmers. Wheat, rice, maize, barley, sorghum, millet and root crops are the basis

Received June 16, 2014. Accepted March 16, 2015. Corresponding author: lemes.elisa@yahoo.com.br of human nutrition worldwide. Of these, wheat has been particularly important, representing the principal grain on which agriculture in the Middle East was founded; since then, wheat has successfully spread around the world. Today, wheat is grown throughout temperate, Mediterranean and sub-tropical climates worldwide and contributes $27 \%$ of total cereal production. Like rice and maize, wheat is essential for human civilization. With more than 215 million hectares planted annually, wheat is the most widely cultivated cereal in the world; this grain is the most important 
protein source and provides approximately $20 \%$ of global calories for human consumption. At approximately 130 million tons, the annual global wheat trade is higher than those of maize and rice combined. More than $60 \%$ of wheat is produced in emerging and developing countries: China and India together produce almost twice as much wheat as the USA and Russia combined. In North Africa and in West and Central Asia, wheat is the dominant staple crop and provides between 40 and $50 \%$ of all calories (Wheat Initiative, 2013).

Brazil has a wheat growing area of approximately 2.5 million ha, yielding an average of approximately $2,600 \mathrm{~kg} \mathrm{ha}^{-1}$ of grain with a total output exceeding 6.0 million tons (Conab, 2013). The cropping area is concentrated in the South and South-Central Regions of Brazil, and the main producing states are Parana, Rio Grande do Sul and São Paulo. The South Region accounts for over $90 \%$ of the country's wheat production.

One possible factor explaining the low national average yield is the use of low-quality seed, which reflects the low input invested in this crop because it is considered of secondary importance compared to soybean and corn. Therefore, among many issues that need attention to meet the demand for self-supplied wheat and improve its production potential, the use of high-quality seeds appears to be of high priority (Tunes, 2011).

High-quality seeds have the ability to produce vigorous stands under a variety of climates and soil conditions. The potential of these seeds to improve yields might warrant their use (Peske et al., 2012).

Seed quality refers to genetic, physical, physiological and sanitary features that, when assessed in an integrated fashion, provide knowledge regarding the real value and potential use of seeds (Carvalho and Nakagawa, 2000).

Continued population growth exerts pressure to improve the technology applied to food produc- tion; thus, the use of mineral nutrients and highquality seeds is essential to increase productivity (Tunes, 2011). Technologies such as the use of micronutrients including zinc through seed coating have contributed to the sustainability of current production systems (Tunes, 2011). This micronutrient is an enzyme activator that is involved in the control of the endogenous concentration of indole acetic acid, which is the main phytohormone responsible for the longitudinal growth of plant cells. Therefore, the clearest symptoms of zinc deficiency are small plants, light green areas between the veins of new leaves, small leaves and short internodes (Oliveira et al., 2003). Within this context, the incorporation of new technologies provides further productivity enhancements, and the seed industry has been a major beneficiary of this process. Seed treatment in particular is gaining acceptance due to its ability to enhance seedling growth and plant stands (Goulart and Melo Filho, 2002). The objective of this research is to evaluate the effect of coating wheat seeds with zinc sulfate on traits that are related seed quality during storage and nutrition efficiency during seedling growth.

\section{Material and methods}

The experiments were performed at the seed testing laboratory for the Postgraduate Program in Seed Science and Technology at the Federal University of Pelotas (Brazil) (Laboratório Didático de Análises de Sementes do Programa de PósGraduação em Ciência e Tecnologia de Sementes da Universidade Federal de Pelotas - UFPel) and at the Laboratory for Analytical Chemistry at the Department of Chemistry of the Federal University of Pelotas (UFPel).

Seeds of the wheat cultivar BRS Guamirim were used. A week after harvesting, the seeds were sent to the laboratory. Wheat seeds from the 2009/2010 harvest season were provided by Sementes Roos \& CIA. Ltda., which is located in the municipality of Não-Me-Toque/RS, Brazil. 
The $\mathrm{Zn}$ source used in this work was zinc sulfate $\left(\mathrm{ZnSO}_{4}\right)$ under the commercial name of Quimifol Seed 78; this material contained $78 \mathrm{~g}$ of $\mathrm{Zn}$ per $100 \mathrm{~mL}$ of commercial product $\left(757.50 \mathrm{~g} \mathrm{~L}^{-1}\right)$. Five concentrations were applied $(0,1,2,3$ and $4 \mathrm{~mL} \mathrm{ZnSO} \mathrm{kg}^{-1}$ seed) together with $3 \mathrm{~mL}$ of fungicide (Carboxim + Thiram), and $0.8 \mathrm{~mL}$ of polymer Poly Seed CF ${ }^{\circledR}$. Water was added to complete the required spray volume of $15 \mathrm{~mL} \mathrm{~kg}^{-1}$ of seed. This fungicide was chosen because it is suitable for this culture and is the most widely used. The polymer was included because it allows improved handling of the materials used and provides protection against sudden changes of water absorption by the seed. Following these treatments, the seeds were stored at room temperature for six months; this storage period represents normal seed storage after harvest until the next sowing. Seed water content at the beginning of storage was between 12.4 to $12.7 \%$, and this level was maintained during all evaluated storage periods.

After 0,3 and 6 months storage, seed quality was determined based on germination, root length, root dry mass and seedling emergence.

Germination (G) was estimated based on four replicates of 100 seeds, which were placed on rolls of towel paper moistened with distilled water at the ratio of 2.5 times the mass of the dry paper. The rolls were placed inside plastic bags and maintained in a germination chamber at $20{ }^{\circ} \mathrm{C}$. The seedlings were counted eight days after sowing, and the results are expressed as the percentage of normal seedlings (Ministério da Agricultura, Pecuária e Abastecimento, Brasil, 2009).

Average root length (ARL) was measured using a millimeter-graduated ruler after four days in the germination chamber using ten normal seedlings that were chosen at random from four replicates of 30 seeds placed on the upper third of the sheet of towel paper, as described by Nakagawa (1999); the result is expressed in centimeters $(\mathrm{cm})$.
Root dry mass (RDM) was measured by separating the shoots from roots immediately after root length measurement and weighing the roots. Then, the root material was placed in cylindrical aluminum capsules $(60 \times 40 \mathrm{~mm})$ and dried in a forced-draught oven at $65{ }^{\circ} \mathrm{C}$ for $96 \mathrm{~h}$. The dry root mass was determined using a precision scale (0.0001 mg), and the results are expressed as $\mathrm{g}$ seedling $^{-1}$, as recommended by Nakagawa (1994).

Seedling emergence (SE) was measured as follows: Four replicates of 50 seeds for each treatment were sown in plastic trays containing a sandy substrate at a depth of $2.0 \mathrm{~cm}$ and maintained at a temperature of $25^{\circ} \mathrm{C}$ in a controlled environment with constant lighting. Irrigation was applied as needed, and seedling emergence was counted 15 days after sowing, when seedling emergence rate was stable. The results are expressed as the percentage of emerged normal seedlings (Nakagawa, 1999).

A completely randomized experimental design with four replicates was used for all tests. Treatment means were subjected to analyses of variance and regression. When no consistent fit was obtained for the regression curve, the Tukey test was applied at the 5\% probability level to test mean differences (Ferreira, 2000).

\section{Response of wheat seedlings to $\mathrm{ZnSO}_{4}$ application}

Eight replicates (of 12 seeds each) per treatment were sown in rectangular plastic containers $(8.0$ $\times 29.0 \times 42.0 \mathrm{~cm})$ at a depth of $2.0 \mathrm{~cm}$ and maintained at $20^{\circ} \mathrm{C}$ in a controlled environment with constant lighting. Soil mineral contents were as follows: clay $=17 \%$, SMP index $=6.3 \%$; organic matter $(\mathrm{OM})=2.2 \%$, phosphorus $(\mathrm{P})=14.3 \mathrm{mg}$ $\mathrm{dm}^{-3}$; potassium $(\mathrm{K})=261.0 \mathrm{mg} \mathrm{dm}^{-3}$ and zinc $(\mathrm{Zn})=0.45 \mathrm{mg} \mathrm{dm}^{-3}$. Irrigation was applied as needed. Seedlings were removed from the containers 20 days after sowing, when the average shoot length ranged between 10 and $15 \mathrm{~cm}$. The 
seedlings were then washed with running water and submerged in a solution of $10 \mathrm{~g} \mathrm{~L}^{-1}$ EDTA for $15 \mathrm{~min}$ to allow the removal of ions bonded to the seedling surfaces, after which the seedlings were washed again in tap water for two minutes. Each seedling was cut at crown level to separate the shoot from the root; then, all the shoot and root material from each replicate was placed in individual paper bags and oven dried at $65^{\circ} \mathrm{C}$ for 96 h (Nakagawa, 1994).

Root extracts were obtained through nitroperchloric digestion; four 0.2-g dry matter (DM) samples were placed in digestion tubes. Pure, concentrated nitric acid $\left(\mathrm{HNO}_{3}-5 \mathrm{~mL}\right)$ was added to each tube, and the tubes were incubated for one hour. All tubes were then placed in a digestion block at $100{ }^{\circ} \mathrm{C}$ for four and a half hours. After removal from the digestion block, the tubes were allowed to cool for $30 \mathrm{~min}$, and an additional 2 $\mathrm{mL}$ of perchloric acid $\left(\mathrm{HClO}_{4}\right)$ was added to the substrate. The tubes were returned to the digestion block for 6 to $8 \mathrm{~h}$ until complete evaporation of the organic matter. Digestion was terminated when the solution exhibited a white and dense smoke of perchloric acid. The samples were rapidly cooled, and the tubes were then sealed with aluminum foil. Due to the high amount of fiber in the plant material, it was necessary to filter all samples using a strainer. Distilled water $(10 \mathrm{~mL})$ was added by gently shaking the tubes to rinse the inner walls; the mineral contents were then determined according to Bataglia et al. (1983). Zinc concentration was determined using atomic absorption spectrometry (Malavolta et al., 1997).

\section{Effect of $\mathrm{ZnSO}_{4}$ dose on nutritional efficiency}

The following indices were calculated based on the nutrient content in the DM substrate:

a) Absorption efficiency= (total content of plant nutrients) / (root DM), according to Swiader et al. (1994); b) Transport efficiency $=$ (root nutrient content) / (whole plant nutrient content) $\times 100$, according to Li et al. (1991), and

c) Use efficiency $=(\text { total DM output })^{2} /($ whole plant nutrient content), according to Siddiqi and Glass (1981).

The experimental design was completely randomized using four replicates. The experimental data were subjected to analysis of variance and regression, and if no significant fit could be established for the regression curve, the treatment means were compared using the Tukey test at the $5 \%$ probability level. Statistical analysis was performed using the SISVAR statistical package (Ferreira, 2000).

\section{Results and discussion}

Figure 1A shows data regarding the initial germination of seeds that had been stored for three to six months. No significant difference in the germination potential was found for seeds treated with different doses of zinc sulfate for any of the studied storage periods. These results are consistent with those obtained by Ohse et al. (2000), who found no differences in germination between zinc-coated and untreated seeds. Vieira and Moreira (2005) found no difference in the germination of zinc-coated and untreated rice. In addition, Fungueto (2010), while analyzing rice seed coated with various zinc sources, fungicide and polymers, found no difference in the percentage of germination. However, Yagi et al. (2006) reported that the germination percentage of seeds was reduced by treatment with zinc. Similar results were observed by Pereira et al. (2005) for film-coated corn seeds, recording a $2 \%$ reduction in germination. Trentini et al. (2005), found no differences in the germination of conventional soybeans and soybeans that were film-coated with AGL 205 and fungicide. The differences between the results described above might be explained by possible differences in nutrient use efficiency between cultures (Oliveira et al., 2003). 
Seedling root length (Figure 1B) was unaffected by the dose of $\mathrm{ZnSO}_{4}$ during the first samplings. Wheat seedlings exhibited a thicker and more developed root system when seeds were coated with $3 \mathrm{~mL} \mathrm{ZnSO}_{4}$, and 20 and $49.5 \%$ increases were observed the same trait for the three- and six-month storage periods, respectively. Ohse et al. (2000) compared the effects of the micronutrients zinc, boron and copper on the growth of rice seedlings and found longer shoots and roots after zinc treatment: shoot length was increased by $9.3 \%$ and root length was increased by $5.1 \%$. Oliveira et al. (2003) reported significantly positive responses of two rice cultivars to Zn, and Barbosa Filho et al. (1994) and Leão (1990) found that seedling shoot height was significantly increased for seeds that had been treated with zinc.
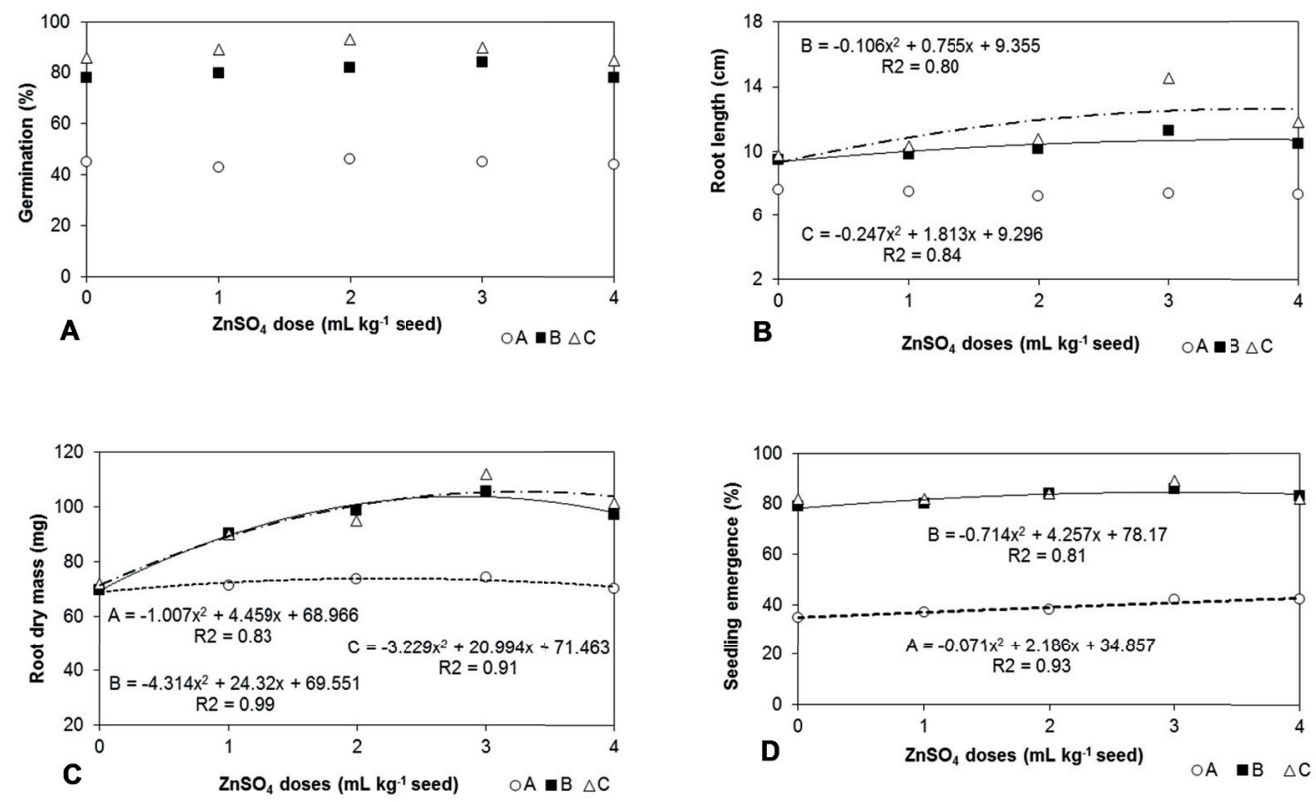

Figure 1. Germination (A), root length (B), root dry mass (C) and seedling emergence (D) of wheat seeds coated to different doses of $\mathrm{ZnSO}_{4}\left(0,1,2,3\right.$ and $\left.4 \mathrm{~mL} \mathrm{ZnSO} \mathrm{kg}{ }^{-1}\right)+$ fungicide (Carboxim Thiram) + polymer + water kg-1 seed, wich were evaluated in the periods: A) Data for first germination count , B) Three months storage and C) Six months storage.

Studies involving the seeds of other species have identified zinc as an enhancer of radicle growth, for example, in rice (Ohse et al., 2000), maize (Roselan and Franco, 2000), sorghum (Yagi et al., 2006), common bean (Martinez et al., 2005) and wheat (Prado et al., 2007). However, Fungueto et al. (2010) observed no difference in shoot growth at various zinc doses; however, increased boron concentrations decreased root weight/length.

Root dry masses are presented in Figure 1C; increasing root dry weight outputs are associ- ated with their respective lengths. Root dry mass, as shown in Figure 2, was highest when using $3 \mathrm{~mL} \mathrm{ZnSO}_{4}$ throughout the entire storage period. When seeds that had been treated with $3 \mathrm{~mL} \mathrm{ZnSO}_{4}$ were stored for six months, root DM was higher by $55.6 \%$, compared to the control. The decreased seedling root DM observed after treatment with $4 \mathrm{~mL} \mathrm{ZnSO}_{4}$ might be due to zinc toxicity, which is characterized by the inhibition of root elongation, thus yielding lower root DM values (Fungueto et al., 2010). 

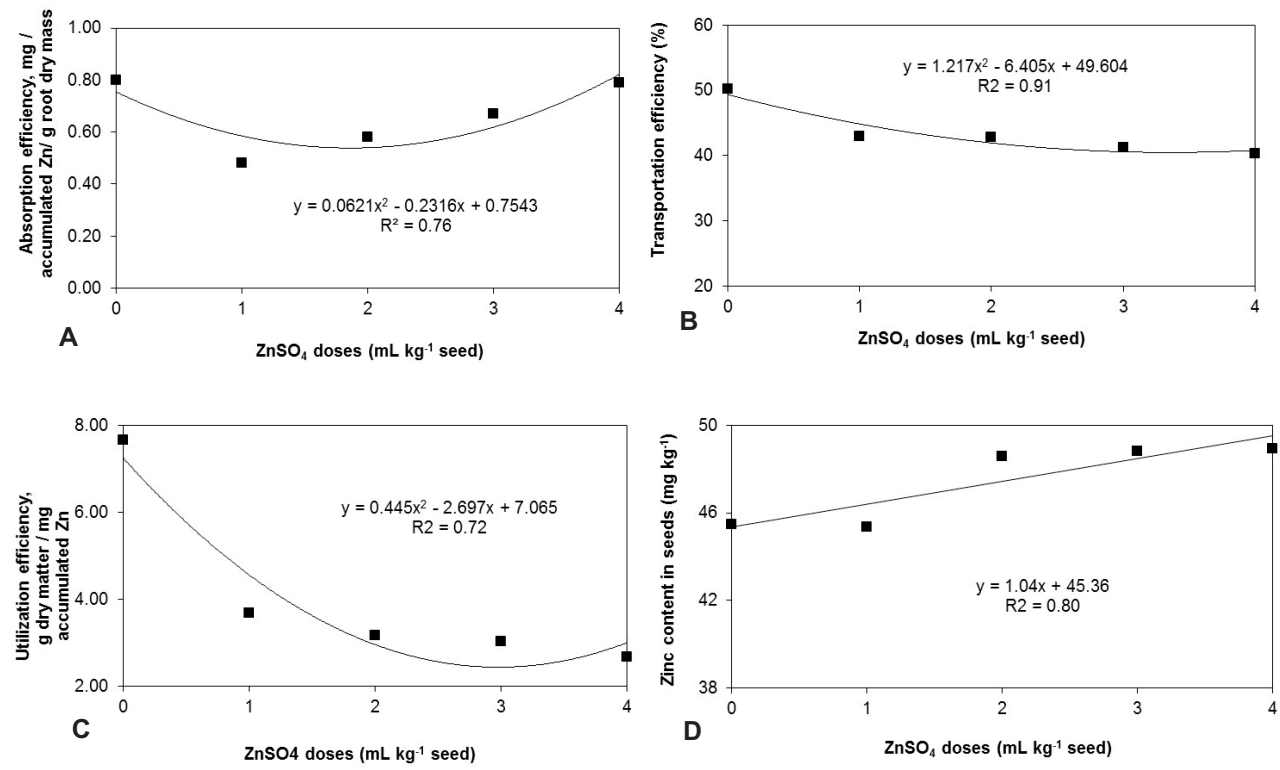

Figure 2. Absorption efficiency of $\mathrm{Zn}(\mathrm{A})$, transport efficiency of $\mathrm{Zn}(\mathrm{B})$, utilization efficiency of $\mathrm{Zn}(\mathrm{C})$ and $\mathrm{Zn}$ content in seed (D) of wheat seeds with different doses of $\mathrm{ZnSO}_{4}\left(0,1,2,3\right.$ and $\left.4 \mathrm{~mL} \mathrm{ZnSO} \mathrm{kg}^{-1}\right)+$ fungicide $($ Thiram + Carboxim $)+$ polymer + water $\mathrm{kg}^{-1}$ seed.

According to Fungueto et al. (2010), this increase in dry mass occurs because zinc plays an important role as a growth promoter by participating in various metabolic pathways that are responsible for seedling growth, thereby increasing the active photosynthetic area and eventually increasing seedling dry biomass.

Initial seedling emergence and emergence after three months of storage (Figure 1D) were highest in seeds that had been coated with $3 \mathrm{~mL}$ of $\mathrm{ZnSO}_{4}$. According to Albuquerque et al. (2010), $\mathrm{Zn}$, when applied to seeds, can be completely absorbed by the seedlings, especially when grown in a sandy substrate, thus preventing nutrient losses. In addition, the difference initial seedling emergence and emergence between the control and various zinc levels can be explained by the direct contact of roots with the mineral (Prado et al., 2007), which might enhance germination and vigor (Ribeiro and Santos, 1996). Wheat seedlings also exhibited enhanced performance after seed treatment with $\mathrm{ZnSO}_{4}$ (Prado et al., 2007).
The zinc content of roots showed a linear response to increasing application doses of $\mathrm{ZnSO}_{4}$ to the seeds (Figure 3A). Zinc levels in the seedling roots in the $4 \mathrm{~mL} \mathrm{ZnSO}_{4}$ treatment increased by $79.7 \%$ compared to the control treatment, with an absolute value of $448.68 \mathrm{mg} \mathrm{kg}^{-1}$. However, this value can be considered toxic for the development of wheat seedlings because the RDM was reduced by $13.9 \%$ in the $4 \mathrm{~mL} \mathrm{ZnSO}_{4}$ treatment. The highest RDM was found in the $3 \mathrm{~mL} \mathrm{ZnSO}_{4}$ treatment, corresponding to a root $\mathrm{Zn}$ content of $394.85 \mathrm{mg} \mathrm{kg}^{-1}$.

Differences in the $\mathrm{Zn}$ content of plant tissues between this work and previous studies are mainly due to the experimental conditions used; i.e., to differences in the soil or substrates employed, as well as to the duration of sample collection. Furthermore, the different cultivars tested by Borket et al. (1998) exhibited variation in $\mathrm{Zn}$ content at levels considered critical for toxicity.

The greater accumulation of $\mathrm{Zn}$ in roots compared to the shoots might occur because the roots act as 

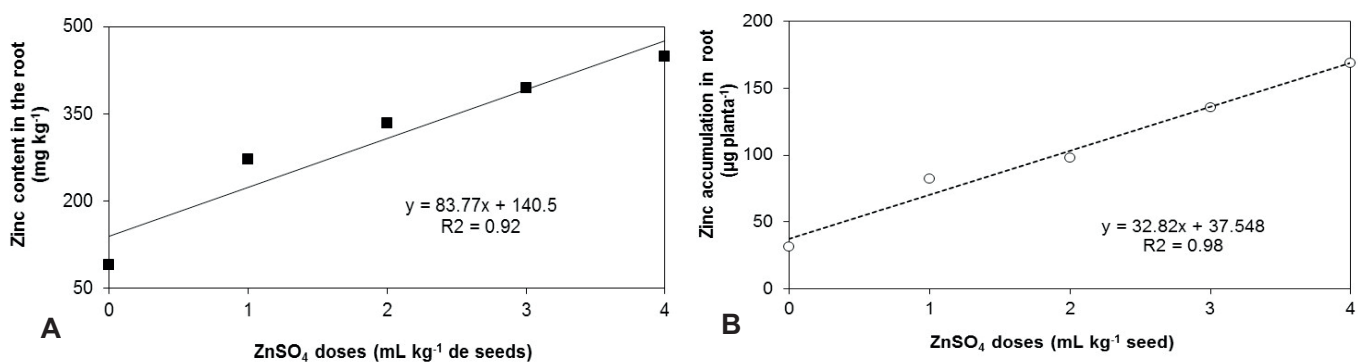

Figure 3. Zinc content in root (A), zinc accumulation in roots (B) of wheat seedling originated from seeds coated to different doses of $\mathrm{ZnSO}_{4}\left(0,1,2,3\right.$ and $\left.4 \mathrm{~mL} \mathrm{ZnSO}_{4} \mathrm{~kg}^{-1}\right)+$ fungicide (Thiram + Carboxim) + polymer + water kg-1 $\mathrm{seed}^{\text {. }}$

an element barrier, thus decreasing the likelihood of plant toxicity. Plant tolerance to excess $\mathrm{Zn}$ is related to its capacity to exudate chelating substances from the roots, thus binding the element by electrical charges within the cell walls or by the formation of various $\mathrm{Zn}$ compounds with organic and inorganic acids, phytates and phytochelatins that are present in the cytoplasm (Wang and Evangelou, 1994).

Finally, these new compounds are stored in vacuoles, thus rendering them less toxic to the plant. However, because the chemical analysis considers whole plant tissue, high concentrations of these products might not cause toxicity symptoms.

Higher seed coatings of $\mathrm{ZnSO}_{4}$ caused the accumulation of $\mathrm{Zn}$ in seedling RDM (Figure 3B), reaching $228.83 \mu \mathrm{g}_{\text {plant }}{ }^{-1}$ at the highest dose tested. Bingham et al. (1975) and Calkmak et al. (1989) reported similar results in grasses and in common bean; $\mathrm{Zn}$ exhibited greater accumulation in the roots than in the shoots.

As seen in Figure 2A, zinc sulfate presented the maximum absorption efficiency (79\%) at a dose of $4 \mathrm{~mL}$, and the lowest efficiency was observed in the control treatment $\left(0 \mathrm{~mL} \mathrm{ZnSO}_{4}\right)$; these findings might be due to a higher accumulation of RDM Zn due to nutrient limitation (Rozane et al., 2008).

$\mathrm{Zn}$ transport efficiency is shown in Figure 2B. Higher levels of $\mathrm{ZnSO}_{4}$ resulted in a significant decrease in the transportation efficiency of this nutrient in a quadratic relationship. The efficiency of $\mathrm{Zn}$ transportation for the zero dose (control) was higher than that for all higher doses. These results might be explained by the low concentration of zinc in the substrate and the fact that all $\mathrm{Zn}$ seed content was transported to the shoots due to its physiological role in plant nutrition. The concentration of zinc present in the seeds was $45.63 \mathrm{mg} \mathrm{kg}^{-1}$.

Gao et al. (2005) reported that in rice, zinc transport efficiency is an important productivity trait, explaining $53 \%$ of the variation in yield among different cultivars. Additionally, the shoot $\mathrm{Zn}$ content of different rice cultivars might vary when high concentrations of $\mathrm{Zn}$ are supplied due to enhanced $\mathrm{Zn}$ translocation from the roots to the shoots (Irri, 1969).

Figure $2 \mathrm{C}$ shows a decreasing trend of $\mathrm{Zn}$ efficiency use with increasing $\mathrm{ZnSO}_{4}$ seed-coat concentration. The lowest $\mathrm{Zn}$ efficiency use was $2.68 \mathrm{DM} \mathrm{mg}^{-1}$ of $\mathrm{Zn}$ accumulation, corresponding to the highest dose of $\mathrm{ZnSO}_{4}$ seed coating. The response of rice cultivars IAC162 and IAC 202 to zinc supply was measured. $\mathrm{Zn}$ use efficiencies were 3.79 and $6.67 \mathrm{~g} \mathrm{DM} \mathrm{mg}^{-1}$ of $\mathrm{Zn}$ for the rice cultivars IAC162 and IAC 202, respectively, indicating that cultivar IAC 202 exhibited superior Zn use efficiency (Oliveira et al., 2003). Similar work by Malavolta et al. (2002) indicated the superiority of cultivar IAC 202 over cultivar 
IAC 165 regarding the conversion efficiency of absorbed $\mathrm{Zn}$ into kernels.

The zinc content of the wheat seeds is shown in Figure 2D. At the doses of 0 and $1 \mathrm{~mL}$ of $\mathrm{ZnSO}_{4}$, the zinc content of the seeds was close to that obtained for seeds from the previous harvest season (i.e., $45 \mathrm{mg}$ and $63 \mathrm{mg} \mathrm{kg}^{-1}$, respectively). It is likely that $\mathrm{Zn}$ originating from the soil $\left(0.45 \mathrm{mg} \mathrm{dm}^{-3}\right)$ and from the seed reserves might have provided adequate zinc to seedlings in the control treatment; Fageria (2000) reported that $0.3 \mathrm{mg} \mathrm{dm}^{-3}$ is an adequate $\mathrm{Zn}$ soil concentration for wheat, and significant quadratic responses to $\mathrm{Zn}$ soil concentration have been established for wheat, rice, corn and soybean. Common beans represent an exception to these findings.

The rate of increase of seed $\mathrm{Zn}$ per unit increase of $\mathrm{ZnSO}_{4}$ applied as a seed coating was $1.4 \mathrm{mg}$ $\mathrm{kg}^{-1}$, and seedling nutritional status significantly affected $\mathrm{Zn}$ transportation. These observations are consistent with reports by Riceman and Jones (1958) and McGrath and Robson (1984), who recorded greater translocation of $\mathrm{Zn}$ from shoots to seeds in environments that supply adequate zinc than in plants grown under limited Zn supply. Clark (1990) found that rice and corn are more sensitive to zinc deficiency, whereas wheat is the most efficient at using this nutrient.
These results obtained in this work and those obtained by Rosane and Santos (1996) indicate that $\mathrm{Zn}$ cannot be considered an immobile element within the plant because higher $\mathrm{ZnSO}_{4}$ concentrations applied as a seed coating are later reflected in increased concentrations of this nutrient in the shoot. High shoot $\mathrm{Zn}$ concentrations ultimately lead to seeds with higher $\mathrm{Zn}$ contents. Treatment with $3 \mathrm{~mL}$ of $\mathrm{ZnSO}_{4}$ provided the highest seed quality. Zinc applied to seed wheat is primarily accumulated in the roots. The application of $\mathrm{ZnSO}_{4}$ to seed wheat resulted in a higher absorption efficiency and lower transportation and use efficiencies of $\mathrm{Zn}$ in response to increasing concentrations of the nutrient.

The supply of micronutrients in seed coatings is efficient because small quantities of these nutrients are required by plants; seed coating allows improved distribution uniformity and lower cost as well as guarantees plant nutrition during early growth stages, while the root system is underdeveloped and nutrients absorption in the soil is lower (Boneccarrére et al., 2004). Here, we observed that the application of appropriate doses of zinc in seed coatings provides improved accumulation of this nutrient, nourishing the plants that can then exhibit improved initial development under adverse conditions.

\section{Resumen}

E.S. Lemes, L.M. Tunes, A.S. Almeida, G.E. Meneghello, S. Oliveira y M.F.B. Muniz. 2015. Respuesta de semillas de trigo a aplicación de zinc durante el almacenamiento. Cien. Inv. Agr. 42(1): 109-119. Recubrimiento de semillas es uno de los tratamientos potencialmente más beneficioso para mejorar el rendimiento de la semilla. También contribuye a proporcionar a los productores con mejores puestos de cultivos derivados de un mejor desarrollo de la plántula, que destaca la posibilidad de uso de micronutrientes como el zinc para el recubrimiento de semillas. El objetivo de esta investigación es evaluar el efecto del recubrimiento de semillas de trigo con sulfato de zinc, en las características relacionados con la calidad de la semilla durante el almacenamiento y la eficiencia nutricional de respuesta durante el crecimiento de plántulas. Las semillas fueron tratadas con 0, 1, 2, 3 y $4 \mathrm{~mL}$ de $\mathrm{ZnSO}_{4}$ por $\mathrm{kg}$ de semillas. Después de un período de 0,3 y 6 meses de almacenamiento fueron evaluados porcentaje de germinación, la longitud media de la raíz, materia seca de la raíz, la emergencia de plántulas, eficiencia nutricional (absorción, transporte y uso) y el contenido de zinc en las semillas. Recubrimiento de semillas con $\mathrm{ZnSO}_{4}$ aumentó materia seca de plántulas y el contenido de zinc en las raíces. 
Por lo tanto, con los resultados obtenidos en este estudio, se observó que la aplicación de dosis apropiadas de zinc en las semillas proporciona una acumulación de este nutriente que se traduce en una planta bien alimentada, que presentan un mejor desarrollo inicial en condiciones adversas.

Palabras clave: Triticum aestivum L. vigor de semillas. tratamiento de semillas.

\section{References}

Albuquerque, K.A.D., J.A. Oliveira, P. de A. Silva, A.D. Veiga, B.O. Carvalho, and P. de O. Alvim. 2010. Armazenamento e qualidade de sementes de tomate enriquecidas com micronutrientes e reguladores de crescimento. Ciência e Agrotecnologia 34:20-28.

Barbosa Filho, M.P., J.F. Dynia, and N.K. Fageria. 1994. Zinco e ferro na cultura do arroz. Brasília: Empresa Brasileira de Pesquisa Agropecuária (EMBRAPA-SPI). Brasilia, Brasil. 71 pp.

Bataglia, O.C., A.M.C. Furlani, J.P.F. Teixeira, P.R. Furlani, and J.R. Gallo. 1983. Métodos de análise química de plantas. Campinas: Instituto Agronômico. Campinas, Brasil. Boletim técnico, 78. 48 pp.

Bingham, F.T., A.L. Page, R.J. Mahler, and T.J. Ganje. 1975. Growth and cadmium accumulation of plants grown on a soil treated with cádmiumenriched sewage sludge. Journal Environmental Quality 4: 207-211.

Borket, C.M., F.R. Cox, and M.R. Tucker. 1998. Zinc and copper toxicity in peanut, soybean, rice and corn in soil mixtures. Communications in Soil Science and Plant Analysis 29: 2991-3005.

Ministério da Agricultura, Pecuária e Abastecimento, Brasil. 2009. Regras para análise de sementes. Ministério da Agricultura, Pecuária e Abastecimento. Brasília, Brasil. 399 pp.

Calkmak, K., H. Marschner, and F. Bangerth. 1989. Effect of zinc nutritional status on growth, protein metabolism and levels of índole-3-acetic acid and other phytohormones in vean (Phaseolus vulgaris L.). Journal of Experimental Botany 40: 405-412.

Carvalho, N.M., and J. Nakagawa. 2000. Sementes: ciência, tecnologia e produção. Jaboticabal: Fundação de Apoio a Pesquisa (Funep). Jaboticabal, Brasil. 4. ed., 588p.
Clark, R.B. 1990. Physiology of cereals for mineral nutrient uptake, use and efficiency. In: Baligar, V.C., and R.R. Duncan. (eds.). Crops as enhancers of nutrient use. Academic Press. San Diego, US. p. 131-209.

Conab - Companhia Nacional de Abastecimento. 2013. Acompanhamento de safra brasileira: grãos, quarto levantamento, janeiro 2013. Available online at: <http://www.conab.gov.br/ conabweb/download/safra $>$ (Website accessed: May 18, 2013).

Fageria, N.K. 2000. Níveis adequados e tóxicos de zinco na produção de arroz, feijão, milho, soja e trigo em solo de cerrado. Revista Brasileira de Engenharia Agrícola e Ambiental 4: 390-395.

Ferreira, D.F. 2000. Análises estatísticas por meio do SISVAR para windows versão 4.0. (ed.) Reunião Anual da Região Brasileira da Sociedade Internacional de Biometria, 45. São Carlos. Anais. São Carlos: Universidade Federal de São Carlos (UFSCAR). p. 225-258.

Fungueto, C.I., J.F. Pinto, L. Baudet, and S.T. Peske. 2010. Desempenho de sementes de arroz irrigado recobertas com zinco. Revista Brasileira de Sementes 32:117-123.

Gao, X., C. Zou, F. Zhang, S.E. Van der Zee, and E. Hoffland. 2005. Tolerance to zinc deficiency in rice correlates with zinc uptake and transolcation. Plant and Soil 278: 253-261.

Goulart, A.C.P., and G.A. Melo Filho. 2002. Tratamento de Sementes - Vale a pena tratar? Revista Cultivar ano IV, 44: 11-13.

Irri - Internacional Rice Research Institute. 1969. Zinc nutrition of rice. In: Annual Report 1969, Los Baños. Proceedings... Philippines: [s.n]. p.155-161.

Leão, R. M. A. 1990. Efeitos do fósforo e do zinco no comportamento do arroz de sequeiro em Latossolo Vermelho Escuro sob vegetação de cer- 
rado. 124f. Dissertação (Mestrado em Ciência do Solo) - Universidade Federal de Santa Maria, Santa Maria, RS, Brasil.

Li, B., S. E. Mckeand, and H.L. Allen. 1991. Genetic variation in nitrogen use efficiency of loblolly pine seedlings. Forest Science, Amsterdam, 37:613-626.

Malavolta, E., R. Heinrichs, C.P. Cabral, S.C. de Oliveira, G. Szakacs, R.S. de Almeida, W.J.O. Souza, and M. Malavolta. 2002. Resposta de dois cultivares de arroz ao zinco em solução nutritiva. Revista de agricultura 77: 195-208.

Malavolta, E., G.C. Vitti, G.C., and S.A. Oliveira. 1997. Avaliação do estado nutricional das plantas: principios e aplicações. 2.ed. Associação Brasileira para Pesquisa do potassio e Fosfato POTAFOS. Piracicaba, Brasil. 319 pp.

Martinez, H.E.P., A.V. Zabini, I.A. de L. Franco, and R.F. de Novais. 2005. Translocação e compartimentalização de Zn em função de doses aplicadas em feijoeiro e cafeeiro via radicular. Ciência Rural, Santa Maria 35: 491- 497.

McGrath, J.F., and A.D. Robson. 1984. The influence of zinc supply to seedling of Pinus radiata D. Don. on the internal transport of recently absorbed zinc. Australian Journal of Plant Physiology 11: 165-178.

Nakagawa, J. 1994. Testes de vigor baseados na avaliação das plântulas. In: Vieira, R.D. and Carvalho, N.M. (eds.) Testes de vigor em sementes. Jaboticabal: Fundação de Apoio a Pesquisa (FUNEP). Jaboticabal, Brasil. p. 49-85.

Nakagawa, J. 1999. Testes de vigor baseado do desempenho das plântulas. In: Krzyzanowski, F.C., Vieira, R.D., and J.B. França Neto. (eds.). Vigor de sementes: Conceitos e Teses. Londrina, Brasil. p. 2-1/2-24.

Ohse, S., V. Marodin, O.S. Santos, S.J. Lopes, and P.A. Manfron. 2000. Germinação e vigor de sementes de arroz irrigado tratadas com zinco, boro e cobre. Revista Faculdade Zootecnia Veterinária e Agronomia 7: 73-79.

Oliveira, S.C., M.C.G. Costa, R.C.S. Chagas, T.A.B. Fenilli, R. Heinrichs, C.P. Cabral, and E. Malavolta. 2003. Resposta de duas cultivares de arroz a doses de zinco aplicado como oxissulfato. Pesquisa Agropecuária Brasileira 38: 387-396.

Pereira, C.P., J.A. Oliveira, and J.R.E. Evangelista. 2005. Qualidade fisiológica de sementes de milho tratadas associadas a polímeros durante o armazenamento. Ciência e Agrotecnologia 29:1201-1208.

Peske, S.T., F.A. Villela, and G.E. Meneghello. 2012. Sementes: Fundamentos Científicos e Tecnológicos. 3.ed. Editora Universitária/UFPel. Pelotas, Brasil. 573 pp.

Prado, R.M., E.F.F. Frade Junior, E.R. Mouta, A.C.G. São João, and R.S.S. Costa. 2007. Crescimento inicial e estado nutricional do trigo submetido à aplicação de zinco via semente. Revista Ciência del Suelo y Nutrición Vegetal 7: 22-31.

Ribeiro, N.D., and O.S. Santos. 1996. Aproveitamento do zinco aplicado na semente na nutrição da planta. Ciência Rural, Santa Maria 26: 159-165.

Riceman, D.S., and G.B. Jones. 1958. Distribution of zinc and copper in subterraneam clover (Trifolium subterraneum) grow in culture solutions supplied with graduated amounts of zinc. Australian Journal of Agriculture Research 9: 73-122.

Roselan, C.A., and G.R. Franco. 2000. Translocação de zinco e crescimento radicular em milho. Revista Brasileira de Ciência do Solo 24: 807-814.

Rozane, D.E., R.M. Prado, L.M. Romualdo, and R.R. Simões. 2008. Resposta de Plântulas de arroz cv. BRS Soberana à aplicação de zinco via semente. Ciência e Agrotecnologia 32: 847-854.

Siddiqi, M.Y., and A.D.M. Glass. 1981. Utilization index: a modified approach to the estimation and comparison of nutrient efficiency in plants. Journal of Plant Nutrition 4: 289-302.

Swiader, J.M., Y. Chyan, and F.G. Freiji. 1994. Genotypic differences in nitrate uptake and utilization efficiency in pumpkin hybrids. Journal of Plant Nutrition, Monticello 17:1687-1699.

Trentini, P., M.G.G.C. Vieira, M.L.M. Carvalho, J.A. Oliveira, and J.C. Machado. 2005. Peliculização: desempenho de sementes de soja no estabelecimento da cultura em campo na região de Alto Garças, MT. Ciência e Agrotecnologia 29: 84-92.

Tunes, L.M. 2011. Atributos de qualidade em sementes de trigo recobertas com zinco durante e após 
o armazenamento. Tese (Doutorado em Agronomia) - Universidade Federal de Santa Maria, Santa Maria, Brasil. 104 pp.

Wang, J., and V.P. Evangelou. 1994. Metal tolerance aspects of plant cell wall and vacuole: handbook of plant and crop physiology.The Univesrity of Arizona. Tucson, US. 325 pp.
Wheat Initiative, 2013. Wheat facts. Available online at: http://www.wheatinitiative.org (Website accessed: February 20, 2014).

Yagi, R., F.F. Simili, J.C. de Araújo, R.M. Prado, S.V. Sanchez, C.E.R. Ribeiro, and V.C.M. Barretto. 2006. Aplicação de zinco via sementes e seu efeito na germinação, nutrição e desenvolvimento inicial do sorgo. Pesquisa Agropecuária Brasileira 41: 655-660. 
